\title{
ANALISIS PENERAPAN WITHHOLDING TAX SYSTEM TERHADAP PAJAK PENERANGAN JALAN DI KAB. MINAHASA UTARA PADA PT. PLN (PERSERO) WILAYAH SULUTTENGGO
}

\author{
Sendi Tanod ${ }^{1}$, David Saerang ${ }^{2}$, Winston Pontoh ${ }^{3}$ \\ 1,2,3 Jurusan Akuntansi, Fakultas Ekonomi dan Bisnis, Universitas Sam Ratulangi, Jl. Kampus Bahu, Manado, \\ 95115, Indonesia \\ E-mail : senditanod213@gmail.com
}

\begin{abstract}
Street lighting tax is territorial tax which is paid by the tax payer as electricity supplier, street lighting tax is collected at the same times with electricity bill payment by PLN customers. The purpose of this research is to analyze the application of withholding tax system in terms of cutting, deposit and reporting of Street Lighting Tax by PT. PLN (Persero) Area Suluttenggo. This research uses descriptive analysis method, which is done by interview and documentation. The results of the study show the Road Lighting Tax in the District North Minahasa by PT. PLN (Persero) Area Suluttenggo Region has been in accordance with the Law No.28 of 2009 and regent of the District north Minahasa No.34 of 2016. For liquefaction road tax refund shall be remitted to the regional treasury through a bank Sulut and in a few months in 2016 there shall be a delay in depositing which is not in accordance with the due date of the fifteenth of the ensuing month, in the case of reporting of PT. PLN (Persero) Area Suluttenggo Region has included Local Tax Payer (SSPD) for each month.
\end{abstract}

Keywords: tax holding system, street lightning tax

\section{PENDAHULUAN}

Pajak Penerangan Jalan merupakan salah satu diantara pajak-pajak daerah yang memberikan kontribusi besar bagi Pendapatan Asli Daerah (PAD). Sarana penerangan Jalan disediakan oleh Pemerintah Daerah dimaksudkan untuk meningkatkan kesejahteraan masyarakat, khususnya keamanan, ketertiban dan keindahan daerah (Witantri, 2016)

Menurut Undang-Undang No. 28 Tahun 2009 pasal 52 ayat (1) menyebutkan bahwa "objek Pajak Penerangan Jalan yaitu penggunaan tenaga listrik, baik yang di hasilkan sendiri maupun dari sumber lain". Selanjutnya, pasal 53 ayat (1) menyebutkan "subjek Pajak Penerangan Jalan adalah orang pribadi atau badan yang dapat menggunakan tenaga listrik" dan ayat (2) menyebutkan "wajib Pajak Penerangan Jalan adalah orang pribadi atau badan yang menggunakan tenaga listrik".

Berdasarkan Undang-Undang No. 28 Tahun 2009 tentang Retribusi Daerah dan Pajak Daerah pasal 53 ayat (3) menyebutkan "dalam hal tenaga listrik disediakan oleh sumber lain, wajib Pajak Penerangan Jalan adalah penyedia tenaga listrik". Penerimaan Pajak Penerangan Jalan dapat berasal dari PLN dan bukan PLN sebagaimana dimaksud sebagai penyedia tenaga listrik dalam Undang-Undang tersebut. Dalam hal tenaga listrik disediakan oleh PLN maka pemungutan Pajak Penerangan Jalan dilakukan oleh PLN, dan dalam hal mekanisme dan prosedur penetapan Pajak Penerangan Jalan yang dilakukan oleh PLN ditetapkan melalui keputusan Kepala Daerah.

PT.PLN sebagai perusahan listrik yang menyediakan dan menjual listrik kepada masyarakat menjadi wajib Pajak Penerangan Jalan yang berkewajiban memotong, menyetor, dan melaporkan Pajak Penerangan Jalan kepada Pemerintah Daerah yang bersangkutan berdasarkan masing-masing Peraturan Daerah yang berlaku di setiap daerah, sebagaimana pasal 56 ayat (2) yang berbunyi "Pajak Penerangan Jalan yang terutang dipungut oleh wilayah daerah tempat penggunaan tenaga listrik". Pajak Penerangan Jalan dari tenaga listrik 
yang disediakan oleh PLN, dipungut bersamaan dengan pembayaran rekening listrik berdasarkan nilai jual tenaga listrik yang berupa jumlah tagihan biaya/beban ditambah dengan biaya pemakaian Kwh yang ditetapkan dalam rekening listrik ataupun pembelian token listrik yang sudah dikenakan Pajak Penerangan Jalan.

Berdasarkan Peraturan Daerah, Pajak Penerangan Jalan yang berasal dari PLN yang sebagai penyedia tenaga listrik, PT.PLN (Persero) Wilayah Suluttenggo merupakan pihak ketiga (Withholder) untuk memotong, menyetor dan melaporkan Pajak Penerangan Jalan dari setiap nilai jual tenaga listrik kepada pemerintah daerah di wilayah Suluttenggo. Dalam Peraturan Bupati Kab. Minahasa Utara No.34 Tahun 2016 pasal 1 ayat (19) menyebutkan "Pajak Penerangan Jalan adalah pajak atas pengguna tenaga listrik, baik yang dihasilkan sendiri maupun yang diperoleh dari sember lain". Selanjutnya dalam pasal 1 ayat (20) menyebutkan "PLN adalah PT. Perusahaan Listrik Negara (Persero) Wilayah Suluttenggo".

PT. PLN (Persero) Wilayah Suluttenggo merupakan Perusahaan listrik negara yang bergerak di bidang jasa ketenagalistrikan yang menyediakan pasokan listrik bagi masyarakat Sulawesi utara, Tengah dan Gorontalo. PT. PLN (Persero) Wilayah Suluttenggo merupakan wajib pajak yang wajib memotong, menyetor dan melaporkan Pajak Penerangan Jalan kepada pemerintah daerah yang temasuk di wilayah Suluttenggo berdasarkan Nilai jual tenaga listrik yang diatur oleh Undang-Undang No. 28 Tahun 2009 pasal 54 dan lebih lanjut pasal 56 menyebutkan bahwa di atur berdasarkan Peraturan Daerah. Pemerintah Daerah dan PT. PLN (Persero) Wilayah suluttenggo membuat kesepakatan melalui Perjanjian Kerjasama (PKS) yang disetujui oleh Pemerintah Daerah Kabupaten/Kota dengan PT. PLN (Persero) Wilayah Suluttenggo, sehingga Pemerintah Daerah dan PT. PLN mengetahui dengan jelas apa yang menjadi hak dan kewajiban Pemerintah Daerah serat hak dan kewajiban PT.PLN (Persero) Wilayah Suluttenggo sebagai pihak ketiga (Withholder) sehubungan dengan Pemotongan, Penyetoran dan Pelaporan Pajak Penerangan Jalan.

PT. PLN (Persero) Wilayah Suluttenggo diberikan kewajiban penuh dalam memungut dan memotong Pajak Penerangan Jalan, dan dalam melakukan perhitungan dan pemotongan Pajak Penerangan Jalan sering terjadi kesalahan sehingga mengakibatkan penyetoran Pajak Penerangan Jalan mengalami kurang bayar maupun lebih bayar. Setelah dilakukan pemotongan Pajak Penerangan Jalan PT. PLN (Persero) Wilayah Suluttenggo wajib menyetorkan Pajak Penerangan Jalan untuk setiap bulannya ke Kas Daerah lewat Bank Sulut maupun bank yang ditunjuk oleh Pemerintah Daerah dengan menyampaikan Surat Setor Pajak Daerah (SSPD). Penyetoran di lakukan dengan batas jatuh tempo yang telah disepakati, jika tidak dilakukan atau terlambat maka akan dikenakan sanksi.

Selanjutnya PT. PLN (Persero) Wilayah Suluttenggo wajib membuat laporan setiap bulannya yang dimasukan kepada Pemerintah Daerah maupun memberikan data kepada pemeriksa dalam hal ini bisa Pemerintah Daerah, DPRD maupun BPK. Pemeriksaan dilakukan ketika dibutuhkan atau adanya permintaan dari Pemerintah Daerah sehubungan dengan adanya kurang bayar untuk meminimalisir terjadinya kesalahan perhitungan/pemotongan maupun penggelapan pajak. Sehingga dalam melakukan pemotongan, penyetoran dan pelaporan pajak penerangan PT. PLN (Persero) Wilayah Suluttenggo harus memperhatikan dan sesuai dengan Undang-Undang No. 28 Tahun 2009 serta Peraturan Pemerintah Daerah/Kepala Daerah yang mengatur tentang Pajak Penerangan Jalan.

\section{TINJAUAN PUSTAKA}

\subsection{Konsep Akuntansi}

Bahri (2016:2) Akuntansi adalah seni pencatatan, penggolongan, pengiktisaran, dan pelaporan atas suatu transaksi dengan cara sedemikian rupa, sistematis dari segi isi, dan berdasarkan standar yang diakui umum. 


\subsection{Akuntansi Perpajakan}

Pohan (2013:10) Akuntansi Perpajakan merupakan salah satu dimensi Akuntansi yang menyediakan informasi yang berhubungan dengan aspek perpajakan, tentang bisnis dan transaksi keuangan kepada mereka yang ingin mengelola bisnis dan transaksi keuangan dan aspek perpajakan dari suatu entitas Akuntansi. Dari data Akuntansi, para pengelola bisnis mendapat bahan untuk mengambil keputusan tentang perpajakan.

\subsection{Pengertian Pajak}

Menurut Waluyo (2013:2), menyatakan pajak adalah iuran kepada Negara yang dapat dipaksakan, dan yang terutang oleh yang wajib membayarnya menurut Undang-Undang, dengan tidak mendapat prestasi kembali yang langsung dapat ditunjukan dan yang digunakan untuk membiayai pengeluaran-pengeluaran umum berhubung dengan tugas negara yang menyelenggarakan pemerintahan.

\subsection{Withholding Tax System}

Mardiasmo (2016:10) Withholding tax system merupakan suatu sistem pemungutan pajak yang memberi wewenang kepada pihak ketiga (bukan fiskus dan bukan wajib pajak yang bersangkutan) untuk memotong atau memungut pajak yang terutang oleh wajib pajak.

\subsection{Pengertian Pajak Penerangan Jalan}

Pajak Penerangan Jalan termasuk kedalam pajak tidak langsung. Berdasarkan Undang-Undang No.28 Tahun 2009 Pasal 1, Pajak Penerangan Jalan merupakan pajak atas penggunaan tenaga listrik, baik yang dihasilkan sendiri atau diperoleh dari sumber lain. Pajak Penerangan Jalan dipungut bersamaan dengan pembayaran tagihan listrik, pajak penerangan jalan digunakan untuk membiayai pengeluaran pemerintah dalam penyediaan penerangan jalan.

\subsection{Dasar Hukum Pajak Penerangan Jalan}

Pajak Penerangan Jalan mempunyai dasar hukum, yaitu sebagai berikut:

1. Undang-Undang No.28 Tahun 2009 tentang Pajak Daerah dan Retribusi Daerah.

2. Peraturan Pemerintah No.69 Tahun 2010 tentang Tata Cara Pemberian dan Pemanfaatan Insentif Pemungutan Pajak Daerah dan Retribusi Daerah.

2. Peraturan Menteri Dalam Negeri Republik Indonesia Direktorat Jenderal Keuangan Daerah No. 973/014/KEUDA Tahun 2012.

3. Peraturan Kementerian Keuangan Republik Indonesia Direktorat Jenderal Perimbangan Indonesia No. 19/PK/2012.

4. Peraturan Daerah Provinsi/Kabupaten/Kotamadya tentang Pajak Daerah.

5. Peraturan Bupati/Kepala Daerah tentang Pajak Daerah.

\subsection{Objek Pajak Penerangan Jalan}

Menurut Undang-Undang No.28 Tahun 2009 pasal 52 ayat (1) “Objek pajak penerangan jalan adalah pengguna tenaga listrik, baik yang di hasilkan sendiri maupun yang diperoleh dari sumber lain. Selanjutnya ayat (2) menyebutkan bahwa "listrik yang dihasilkan sendiri sebagaimana dimaksud pada ayat (1) meliputi seluruh pembangkit listrik.

\subsection{Subjek Pajak Penerangan Jalan}

Undang-Undang No.28 Tahun 2009 pasal 53 ayat (1) menyebutkan "Subjek Pajak Penerangan Jalan adalah orang pribadi atau badan yang dapat menggunakan tenaga listrik. Sedangkan yang menjadi wajib pajak dalam pasal (2) yaitu orang pribadi atau badan yang menggunakan tenaga listrik. Lebih lanjut ayat (3) menyebutkan bahwa "dalam hal tenaga listrik disediakan oleh sumber lain, wajib pajak penerangan jalan adalah penyedia tenaga listrik".

\subsection{Tarif Pajak Penerangan Jalan}

Dalam Undang-Undang No.28 Tahun 2009 pasal 55 menyebutkan tarif Pajak Penerangan Jalan yaitu sebagai berikut:

(1) Tarif Pajak Penerangan Jalan ditetapkan paling tinggi sebesar 10\% dan 3\% untuk Industri 
(2) Penggunaan tenaga listrik yang dihasilkan sendiri, tarif Pajak Peneranga Jalan D itetapkan paling tinggi sebesar $1,5 \%$ (satu koma lima persen).

(3) Tarif Pajak Penerangan Jalan ditetapkan dengan PeraturanDaerah.Berdasarkan ayat (4) Undang-Undang No.28 Tahun 2009 yang menyebutkan tarif Pajak Penerangan Jalan ditetapkan oleh Peraturan Daerah, maka Pemerintah Kabupaten Minahasa Utara lewat Peraturan Bupati No.34 Tahun 2016 pasal 71 menyebutkan "Tarif Pajak Penerangan Jalan ditetapkan sebesar $10 \%$ (sepuluh per seratus), untuk Industri minyak dan gas ditetapkan sebesar 3\% (tiga per seratus). Dan untuk Penggunaan listrik yang di hasilkan sendiri ditetapkan sebesar 1,5\% (satu koma lima per seratus).

\subsection{Penelitian terdahulu}

Penelitian terdahulu yang penulis jadikan sebagai bahan pertimbangan dalam melakukan penelitian ini yaitu Penelitian yang dilakukan oleh Senli (2015), tentang Analisis Penerapan Pajak Dengan Withholding Tax System PPh Pasal 4 ayat (2) Pada PT. Bank OCBC NISP Kota Palembang. Dengan hasil penelitian menunjukan bahwa di Bank OCBC NISP telah melaksanakan kewajiban perpajakannya dengan baik dan sesuai denga peraturan perpajakan yang berlaku, hanya saja perlu melakukan integitas pada saat pengimputan suku bunga deposito yang jatuh tempo.

\section{METODE PENELITIAN}

\subsection{Jenis Penelitian}

Penelitian ini termasuk jenis penelitian kualitatif deskriptif. menurut Algifari (2013:7) data kualitatif adalah fakta/angka/hasil/pengukuran yang tidak memiliki satuan dan nol bukanlah nilai absolut, oleh karena itu data kualitatif tidak dapat dilakukan operasi matematis (penjumlahan, pengurangan, perkalian, dan pembagian). Biasanya data kualitatif nilainya dinyatakan dalam ukuran kategori, oleh karena itu data kualitatif juga disebut data kategorik. Data kualitatif dalam penelitian ini diperoleh dari pengumpulan data seperti wawancara, analisis dokumen, diskusi terfokus, atau observasi. Wawancara dilakukan untuk mengetahui bagaimana proses pemotongan, penyetoran dan pelaporan pajak penerangan jalan. Dokumen yang dianalisis adalah data-data atau informasi terkait dengan bukti pemotongan dan penyetoran serta bentuk laporan pajak penerangan jalan.

\subsection{Waktu dan Tempat Penelitian}

Penelitian ini dilaksanakan pada PT. PLN (Persero) Wilayah Suluttenggo. Waktu penelitian dilaksanakan pada bulan Maret 2018. Selama jangka waktu tersebut, dilakukan pengumpulan data, pengolahan data, dan analisis.

\subsection{Prosedur Penelitian} berikut.

Langkah-langkah yang telah dilakukan pada pelaksanaan penelitian yaitu sebagai

1. Menentukan judul penelitian dan merumuskan masalah dengan jelas.

2. Pengumpulan data melalui wawancara terhadap pihak-pihak yang terkait serta pengambilan data-data mengenai pemotongan, penyetoran dan pelaporan pajak penerangan jalan.

3. Mengelola data dan menginterpretasikan hasil pengelolaan data

4. Menarik kesimpulan dan memberikan saran yang dianggap perlu sebagai perbaikan dalam masalah yang ada.

\subsection{Metode Analisis}

Metode analisis data yang digunakan dalam penelitian ini adalah metode deskriptif. Penelitian ini menganalisis Penerapan withholding tax system yaitu pemungutan pajak yang di lakukan pihak ketiga (withholder) dalam hal pemotongan, penyetoran dan pelaporan Pajak Penerangan Jalan yang di lakukan oleh PT. PLN (Persero) Wilayah Suluttenggo. Penelitian deskriptif yang dilakukan dengan wawancara dan dokumentasi. Wawancara pertama 
dilakukan kepada bapak Salim Abas selaku Deputy Manager Keuangan, pertanyaan yang ditanyakan mengenai kegiatan pelaksanaan dan mekanisme Pajak Penerangan Jalan. Selanjutnya wawancara dilakukan dengan ibu Agnes Sembur selaku pihak yang mengkordinir pemotongan, penyetoran dan pelaporan Pajak Penerangan Jalan. Dokumentasi di lakukan dengan mengumpulkan bukti-bukti pemotongan, penyetoran, dan pelaporan Pajak Penerangan Jalan pada bulan Januari sampai dengan Desember 2016. Setelah memperoleh data dari wawancara dan dokumentasi langkah selanjutnya adalah menganalisis data-data yang ada, peneliti menghitung kembali bukti-bukti transaksi pemotongan Pajak Penerangan Jalan yang ada di PT. PLN (Persero) Wilayah Suluttenggo dan mencocokkan tarifnya sesuai dengan Undang-Undang No. 28 Tahun 2009. Selanjutnya peneliti menganalisis bukti penyetoran dan pelaporan Pajak Penerangan Jalan mengenai ketepatan waktu PT. PLN (Persero) Wilayah Suluttenggo menyetorkan dan melaporkan Pajak Penerangan Jalan Kepada Pemerintah Daerah Kab. Minahasa Utara apakah telah sesuai dengan Undang-Undang No. 28 Tahun 2009 dan Peraturan Daerah/Kepala Daerah.

\section{HASIL ANALISIS DAN PEMBAHASAN}

4.1 Hasil analisis

\subsubsection{Pemotongan Pajak Penerangan Jalan}

Pemotongan Pajak Penerangan Jalan yang dilakukan oleh PT.PLN (Persero) Wilayah

Suluttenggo atas Pajak Penerangan Jalan Kab. Minahasa Utara pada bulan Januari 2016 adalah sebagai berikut:

PPJ dari tagihan listrik

Rp. 467.820 .217

PPJ dari non-tagihan listrik:

-Online

Rp. 14.509 .217

-Offline I-06

Rp. -

-Nota Buku

Rp. -

PPJ dari PraBayar:

-Token tunai (online)

Rp. 104.243.549

-Kompensasi TMP

Rp. $\quad 2.006 .471$

-Kompensasi UJL

Rp. - +

Restitusi dari PPJ

Rp. $\quad 32.217-$

Rp. 588.607.183 


\subsubsection{Penyetoran Pajak Penerangan Jalan}

Tabel 4.1

Penyetoran Pajak Penerangan Jalan Kepada Kab. Minahasa Utara

1 Januari 2016 S/D 31 Desember 2016

\begin{tabular}{|c|c|c|c|c|}
\hline $\begin{array}{l}\text { NAMA WAJIB } \\
\text { PAJAK }\end{array}$ & $\begin{array}{l}\text { PEMBAYARAN } \\
\text { PAJAK (BULAN) }\end{array}$ & $\begin{array}{c}\text { TANGGAL } \\
\text { LUNAS BANK }\end{array}$ & $\begin{array}{l}\text { REALISASI } \\
\text { (Rp.) }\end{array}$ & KET \\
\hline \multirow{12}{*}{$\begin{array}{c}\text { PT. PLN } \\
\text { (PERSERO) } \\
\text { WILAYAH } \\
\text { SULUTTEGGO }\end{array}$} & Desember 2015 & $14-01-2016$ & 574.731 .269 & Tepat waktu \\
\hline & Januari 2016 & 19-02-2016 & 588.592 .183 & Tidak tepat waktu \\
\hline & Februari 2016 & $17-03-2016$ & 550.572 .601 & Tidak tepat waktu \\
\hline & Maret 2016 & $15-04-2016$ & 629.550 .187 & Tepat waktu \\
\hline & April 2016 & $18-05-2016$ & 575.992 .688 & Tidak tepat waktu \\
\hline & Mei 2016 & 17-06-2016 & 595.310 .228 & Tidak tepat waktu \\
\hline & Juni 2016 & 19-07-2016 & 626.346 .829 & Tidak tepat waktu \\
\hline & Juli 2016 & $15-08-2016$ & 578.524 .207 & Tepat waktu \\
\hline & Agustus 2016 & $14-09-2016$ & 844.629 .019 & Tepat waktu \\
\hline & September 2016 & $19-10-2016$ & 794.097.409 & Tidak tepat waktu \\
\hline & Oktober 2016 & $11-11-2016$ & 832.026 .550 & Tepat waktu \\
\hline & November 2016 & $15-12-2016$ & 862.076 .651 & Tepat waktu \\
\hline \multicolumn{3}{|c|}{ TOTAL } & 8.052 .449 .821 & \\
\hline
\end{tabular}

Sumber: PT. PLN (Persero) Wilayah Suluttenggo

Dalam Keputusan Menteri Dalam Negeri Republik Indonesia oleh Direktorat Jenderal Keuangan Daerah No. 973/014/KEUDA Tahun 2012 kepada PT. PLN (Persero) pada bagian ke empat menyebutkan "PT. PLN (Persero) menyetor hasil penerimaan Pajak Penerangan Jalan secara bruto ke Kas Daerah atau tempat lain yang ditunjuk oleh Kepala Daerah dengan menggunakan Surat Setor Pajak Daerah (SSPD), penyetoran hasil penerimaan Pajak Penerangan Jalan dilakukan pada bulan berikutnya, paling lambat sesuai tanggal yang ditetapkan dalam Peraturan Daerah dan/atau Peraturan Kepala Daerah". Penyetoran Pajak Penerangan Jalan yang terutang di lakukan oleh PT. PLN (Persero) Wilayah Suluttenggo selaku wajib pajak kepada Kas Daerah lewat Bank Sulut sesuai dengan Undang-Undang No.28 Tahun 2009 dan Peraturan Daerah maupun Peraturan Kepala Daerah/Kota.

\subsubsection{Pelaporan Pajak Penerangan Jalan}

Berdasarkan Keputusan Menteri Dalam Negeri Republik Indonesia Direktorat Jenderal Keuangan Daerah No. 973/014/KEUDA Tahun 2012 kepada PT. PLN (persero) menyebutkan:

1. PT. PLN (persero) membuat daftar rekapitulasi tagihan listrik pelanggan yang telah dilunasi dan disampaikan kepada Kepala Daerah atau pejabat pengelola Pajak Penerangan Jalan.

2. Daftar rekapitulasi tagihan listrik, antara lain memuat data; jumlah pelanggan, dan jumlah pembayaran Penjualan Tenaga Listrik (PTL).

3. Pemerintah Daerah dapat meminta daftar rincian tagihan listrik per pelanggan kepada PT. PLN (Persero) yang pelaksanaannya dikoordinasi antara Pemerintah Daerah dengan PLN unit setempat. 
Tabel 4.2

Pelaporan Pajak Penerangan Jalan PT. PLN (Persero) Wilayah Suluttenggo Kepada Kab. Minahasa Utara Untuk bulan Januari-Desember 2016

\begin{tabular}{|l|l|l|l|}
\hline $\begin{array}{c}\text { PEMBAYARAN } \\
\text { PAJAK (BULAN) }\end{array}$ & $\begin{array}{c}\text { TANGGAL } \\
\text { LUNAS BANK }\end{array}$ & \multicolumn{1}{|c|}{ PELAPORAN } & KETERANGAN \\
\hline Desember 2015 & $14-01-2016$ & $25-01-2016$ & Tepat Waktu \\
\hline Januari 2016 & $19-02-2016$ & $28-02-2016$ & Tepat Waktu \\
\hline Februari 2016 & $17-03-2016$ & $24-03-2016$ & Tepat Waktu \\
\hline Maret 2016 & $15-04-2016$ & $22-04-2016$ & Tepat Waktu \\
\hline April 2016 & $18-05-2016$ & $28-05-2016$ & Tepat Waktu \\
\hline Mei 2016 & $17-06-2016$ & $22-06-2016$ & Tepat Waktu \\
\hline Juni 2016 & $19-07-2016$ & $28-07-2016$ & Tepat Waktu \\
\hline Juli 2016 & $15-08-2016$ & $20-08-2016$ & Tepat Waktu \\
\hline Agustus 2016 & $14-09-2016$ & $21-09-2016$ & Tepat Waktu \\
\hline September 2016 & $19-10-2016$ & $27-10-2016$ & Tepat Waktu \\
\hline Oktober 2016 & $11-11-2016$ & $19-11-2016$ & Tepat Waktu \\
\hline November 2016 & $15-12-2016$ & $21-12-2016$ & Tepat Waktu \\
\hline
\end{tabular}

Sumber: PT. PLN (Persero) Wilayah Suluttenggo (Data diolah, 2018)

\subsubsection{Penerapan Withholding Tax System Terhadap Pajak Penerangan Jalan Berdasarkan Undang-Undang No.28 Tahun 2009}

Undang-Undang No. 28 Tahun 2009 Pasal 54 ayat (1) menyebutkan bahwa "Dasar pengenaan Pajak Penerangan Jalan adalah Nilai Jual Tenaga Listrik". Dalam Undang-Undang No.28 Tahun 2009 Pasal 55, dapat dilihat bahwa tarif Pajak Penerangan Jalan adalah sebagai berikut:

(1) Tarif Pajak Penerangan Jalan ditetapkan paling tinggi sebesar 10\% (sepuluh persen).

(2) Penggunaan tenaga listrik yang berasal dari sumber lain yaitu Industri gasa dan minyak tarif Pajak Penerangan Jalan ditetapkan paling tinggi sebesar 3\% (tiga persen).

(3) Penggunaan tenaga listrik dihasilkan sendiri, tarif Pajak Penerangan Jalan ditetapkan paling tinggi sebesar 1,5\% (satu koma lima persen)

(4) Tarif Pajak Penerangan Jalan ditetapkan dengan Peraturan Daerah.

4.1.5 Penerapan Withholding Tax System Terhadap Pajak Penerangan Jalan Berdasarkan Peraturan Bupati Kab. Minahasa Utara No.34 Tahun 2016

Hak dan Kewajiban PT. PLN (Persero) Wilayah Suluttenggo berdasarkan Peraturan Bupati Kab. Minahasa Utara No.34 Tahun 2016:

1. Dalam hal tenaga listrik berasal dari sumber lain tata cara pendaftaran dilakukan oleh PLN

2. Dalam hal tenaga listrik disediakan oleh PLN maka kewenangan pemungutan Pajak Penerangan Jalan adalah PLN.

3. Dalam hal tenaga listrik berasal dari sumber lain pendataan dilakukan oleh PLN.

4. Pajak Penerangan Jalan yang tenaga listriknya berasal dari sumber lain ditetapkan oleh PLN.

\subsection{Pembahasan}

\subsubsection{Pemotongan Pajak Penerangan Jalan}

Peraturan Daerah Kab. Minahasa Utara No. 2 Tahun 2011 tentang Pajak Daerah dan lebih di lengkapi lagi dalam Peraturan Bupati Minahasa Utara No. 34 tahun 2016 Pasal 71 tentang pengenaan dan tarif Pajak Penerangan Jalan ditetapkan sesuai dengan UndangUndang No. 28 Tahun 2009. Pasal 72 Perbup Minahasa Utara menyatakan tarif Pajak Penerangan Jalan ditetapkan sebesar 10\% (sepuluh per seratus) sesuai dengan Undang- 
Undang No. 28 Tahun 2009 pasal 55 ayat (1) yang berbunyi "tarif Pajak Penerangan Jalan ditetapkan paling tinggi sebesar $10 \%$ (sepuluh persen)".

Pemotongan Pajak Penerangan Jalan oleh PT. PLN (Persero) Wilayah Suluttenggo di lakukan lewat Penggolongan tarif dan bentuk pembayarannya. Untuk golongan tarif Rumah tangga (R) dan Sosial (S) di potong Pajak Penerangan Jalan sebesar 10\% dari total pelunasan penjualan tagihan listrik (PTL) dan untuk golongan tarif Industri di potong Pajak Penerangan Jalan sebesar 3\%.

Namun dalam Pemotongan Pajak Penerangan Jalan yang dilakukan oleh PT. PLN (Persero) Wilayah Suluttenggo pada bulan januari 2016 untuk Pajak Penerangan Jalan yang terhutang kepada Kab. Minahasa Utara masih terjadi kesalahan sehingga terjadi lebih bayar. Penjualan tenaga listrik untuk golongan rumah tangga $(\mathrm{R})$ dengan jumlah transfer 33 dan PTL Rp. 5.022.405 terjadi kelebihan bayar untuk Pajak Penerangan Jalan sebesar Rp.9.950 yang dipotong sebesar 10\% dari PTL, lebih bayar ini bisa dilakukan restitusi yang dapat disampaikan lewat Surat Ketetapan Pajak Daerah Lebih bayar (SKPDLB) dan akan dipotong pada Pajak Penerangan Jalan bulan berikutnya. Pada bulan Januari 2016 juga terdapat restitusi yang mengurangi Pajak Penerangan Jalan bulan tersebut yang diakibatkan dari lebih bayar pada bulan sebelumnya yaitu sebesar Rp, 32.271.

\subsubsection{Penyetoran Pajak Penerangan Jalan}

Menurut pasal 64 ayat (3) Peraturan Bupati Minahasa Utara, menyebutkan bahwa "PLN wajib menyetor hasil pemungutan Pajak Penerangan Jalan paling lambat 15 (lima belas) hari setelah tanggal jatuh tempo". Lebih lanjut pasal 73 ayat (3) menyebutkan bahwa "tanggal jatuh tempo terhitung sejak berakhirnya masa pajak bulan berjalan". Dan ayat (1) menyebutkan bahwa "Masa pajak adalah jangka waktu yang lamanya satu bulan sebagai dasar untuk menghitung besarnya pajak yang terhutang".

Penyetoran Pajak Penerangan Jalan yang dilakukan oleh PT. PLN (Persero) Wilayah Suluttenggo kepada Kab. Minahasa Utara pada bulan Januari sampai dengan Desember 2016 menggunakan Surat Setor Pajak Daerah (SSPD). PT. PLN (Persero) Wilayah Suluttenggo menyetorkan Pajak Penerangan Jalan ke Kas Daerah lewat Bank Sulut, tanggal penyetoran dinyatakan lunas yaitu berdasarkan tanggal lunas bank. Penyetoran yang dilakukan oleh PLN ke Kas daerah Kab. Minahasa Utara lewat bank Sulut untuk tahun 2016 terjadi keterlambatan Penyetoran pada bulan Januari, Februari, April, Mei, Juni, dan September yaitu lewat tanggal 15 sesuai tanggal jatuh tempo. Dan untuk bulan Desember, maret, Juli, Agustus, Oktober dan November telah sesuai yaitu sebelum tanggal jatuh tempo.

\subsubsection{Pelaporan Pajak Penerangan Jalan}

Sebagai wajib pajak PT. PLN (Persero) Wilayah Suluttenggo wajib menyampaikan Surat Pemberitahuan Pajak Daerah (SPTPD). Surat ini adalah surat yang digunakan oleh wajib pajak untuk melaporkan pemotongan dan penyetoran Pajak Penerangan Jalan yang terhutang berdasarkan Undang-Undangan dan Peraturan Daerah

PT. PLN (Persero) Wilayah Suluttenggo telah memberikan laporan Pajak Penerangan Jalan kepada kab. Minahasa Utara berupa daftar Pelunasan Tenaga Listrik (PTL) untuk semua golongan tarif yang telah dilunasi dan telah dilaporkan lewat Surat Pemberitahuan Pajak Daerah (SPTPD) untuk setiap bulannya. Bentuk laporan berupa laporan penerimaan Pajak Penerangan Jalan untuk semua golongan tarif berdasarkan total pelunasan Pajak Penerangan Jalan dari tagihan Listrik, Non Tagihan Listrik (online), PraBayar (Token online), dan pelunasan Pajak Penerangan Jalan dari Kompensasi TMP serta Restitusi atas lebih bayar pada bulan sebelumnya yang dikurangi pada Pajak Penerangan Jalan bulan berikutnya. 


\subsubsection{Penerapan Withholding Tax System Terhadap Pajak Penerangan Jalan Berdasarkan Undang-Undang No.28 Tahun 2009}

Pemotongan Pajak Penerangan Jalan oleh PT. PLN (Persero) Wilayah Suluttenggo telah sesuai dengan Undang-Undang No.28 Tahun 2009, yaitu ditetapkan paling tinggi $10 \%$ dan paling tinggi 3\% untuk industri, pertambangan minyak bumi dan gas alam. Dengan dasar pengenaan Pajak yaitu Jumlah tagihan biaya beban/tetap ditambah dengan biaya pemakaian $\mathrm{kwh} /$ variabel yang ditagihkan dalam rekening listrik sebagaimana yang dimaksud dalam pasal 54 ayat (2).

\subsubsection{Penerapan Withholding Tax System Terhadap Pajak Penerangan Jalan} Berdasarkan Peraturan Bupati Kab. Minahasa Utara No.34 Tahun 2016

PT. PLN (Persero) Wilayah Suluttenggo telah menjalankan kewajibannya sebagai pihak ketiga (withholder) dalam hal pemotongan, penyetoran dan pelaporan Pajak Penerangan Jalan sebagaimana dalam Peraturan Bupati Kab. Minahasa Utara No.34 tahun 2016 pasal 1 ayat (20) yaitu "PLN adalah PT. Perusahaan Listrik Negara (PERSERO) Wilayah Suluttenggo". Pemotongan Pajak Penerangan Jalan telah sesuai dengan Peraturan Bupati Kab. Minahasa Utara No.34 tahun 2016 yaitu 10\% untuk golongan tarif Rumah tangga, Sosial, Bisnis, Pemerintah dan 3\% untuk golongan tarif Industri. Untuk penyetoran belum sesuai dengan pasal 75 ayat (3) yaitu tanggal 15 sesudah tanggal jatuh tempo, karena terdapat keterlambatan waktu penyetoran dalam tahun 2016. Dan untuk pelaporan telah sesuai dengan tanggal yang ditetapkan yaitu bulan berjalan setelah tanggal jatuh tempo, dan PT. PLN (Persero) Wilayah Suluttenggo telah memasukan rekapitulasi rekening listrik yang dicetak per jenis tarif untuk penggunaan listrik pascabayar, rekapitulasi penggunaan voucer listrik isi ulang untuk listrik prabayar, dan rekapitulasi realisasi penerimaan Pajak Penerangan Jalan sebagaiman kewajiban PLN yang tercantum dalam Pasal 64 ayat (4).

\section{KESIMPULAN DAN SARAN}

\subsection{Kesimpulan}

Berdasarkan hasil penelitian dan pembahasan yang dilakukan, maka peneliti menyimpulkan beberapa hal sebagai berikut :

1. PLN sebagai pihak ketiga dalam menjalankan withholding tax system dalam hal pemotongan, penyetoran dan pelaporan Pajak Penerangan Jalan berlandaskan UndangUndang No. 28 Tahun 2009 tetang Pajak Daerah dan Retribusi Daerah serta Peraturan Daerah yang berlaku.

2. Pemotongan Pajak Penerangan Jalan yang di lakukan oleh PT. PLN (Persero) Wilayah Suluttenggo untuk Kab. Minahasa Utara telah sesuai dengan Undang-Undang serta Peraturan daerah yang berlaku yaitu sebesar 10\% dan 3\% untuk industri dari Nilai Jual Tenaga Listrik yang di hitung dari Jumlah Tagihan Biaya Beban/Tetap + Biaya pemakaian $\mathrm{kWh} / \mathrm{variabel} \mathrm{kemudian} \mathrm{dikalikan} \mathrm{tarif} \mathrm{Pajak.}$

3. Penyetoran Pajak Penerangan Jalan di lakukan oleh PT. PLN (Persero) Wilayah Suluttenggo disetor kepada Pemerintah Daerah dalam hal ini Badan keuangan Kab. Minahasa Utara melalui Bank yang di tunjuk dalam Peraturan Daerah yaitu Bank Sulut berdasarkan batas waktu yang di tentukan dalam Peraturan Daerah yaitu lima belas hari setelah tanggal jatuh tempo, dan penyetoran yang dilakukan belum sesuai dengan ketentuan batas waktu yang diberikan, karena terdapat beberapa keterlambatan penyetoran pada tahun 2016.

4. PT. PLN (Persero) Wilayah Suluttenggo berkewajiban melaporkan rekapitulasi Pajak Penerangan Jalam dalam bentuk rekapitulasi rekening listrik yang dicetak per jenis tarif untuk penggunaan listrik pascabayar dan prabayar serta rekapitulasi realisasi penerimaan Pajak Penerangan Jalan, dan dalam hal pelaporan PLN masih belum sepenuhnya bersifat terbuka dalam pemenuhan kewajiban memberikan laporan data pelanggan dan jumlah 
pelanggan yang sulit untuk di dapatkan oleh Pemerintah Daerah, Serta laporan setiap bulan yang seharusnya dimasukan oleh PLN sebaliknya harus di ambil sendiri oleh Pemerintah Daerah di PT. PLN (Persero) Wilayah Suluttenggo

\subsection{Saran}

Berdasarkan hasil penelitian dan pembahasan yang dilakukan, peneliti memberikan beberapa saran sebagai berikut :

1. Sebagai wajib Pajak yang melakukan withholding tax system PT. PLN (Persero) Wilayah Suluttenggo dalam hal pemotongan, penyetoran, dan pelaporan Pajak Penerangan Jalan untuk lebih dapat memperhatikan Undang-Undang dan Peraturan Daerah yang berlaku sehingga terlaksana sesuai dengan ketentuan.

2. Sebaiknya PLN lebih bersifat lebih terbuka dalam pelaporan Pajak Penerangan Jalan Kepada Pemerintah Daerah dan memperhatikan ketepatan waktu pelaporan.

3. Selaku pihak pemotong juga perlu adanya pemeriksaan kembali terhadap pemotongan yang dilakukan sehingga tidak terjadinya kesalahan dalam menghitung dan juga tetap mempertahankan kepatuhan perpajakan yang telah dijaga dan dilaksanakan selama ini agar terhindar dari sanksi pajak.

4. Bagi Pemerintah Daerah yang mempercayakan PT. PLN (Persero) Wilayah Suluttenggo sebagai pihak pemotong, penyetor dan pelapor pajak Penerangan Jalan, untuk dapat membangun kerja sama yang baik dengan PLN, sehingga kewajiban dan hak PLN maupun Pemerintah Daerah bisa berjalan dengan baik.

\section{DAFTAR PUSTAKA}

Algifari. 2013. Statistik Deskriptif plus. Edisi ReSkripsivisi.Yogyakarta: UPP STIM YKPN. Keputusan Menteri Dalam Negeri Republik Indonesia Direktorat Jenderal Keuangan Daerah No. 973/014/KEUDA Tahun 2012.

Mardiasmo. 2016. Perpajakan. Edisi Terbaru 2016. Andi, Yogyakarta.

Pemerintah RI, Undang-Undang No.28 Tahun 2009 Pasal 1 angka 28 tentang Pajak Penerangan Jalan (PPJ).

Pemerintah RI, Undang-Undang RI No.28 Tahun 2009 tentang Pajak Daerah dan Retribusi Daerah

Peraturan Bupati Minahasa Utara No. 36 Tahun 2016 Pasal 71 tentang pengenaan dan tarif Pajak Penerangan Jalan.

Pohan, Chairil Anwar. 2013. Management Perpajakan. Jakarta: Gramedia Pustaka Utama.

Pontoh, Winston. 2013. Akuntansi Konsep dan Aplikasi. Halaman Moeka. Jakarta Barat

Senli. 2015. Analisis Penerapan Pajak Dengan Withholding Tax System Terhadap Pajak Penghasilan Pasal 4 Ayat (2) Pada PT. Bank OCBC NISP. Jurnal Ilmu dan Riset Akuntansi Vol. 7, No. 5: 77-84. 2015. Palembang: STIE MDP.

Waluyo. 2013. Perpajakan Indonesia. Edisi 11. Jakarta: Selemba Empat.

Witantri, Endang. 2016. Pengaruh Jumlah Pelanggan PLN dan Jumlah KWH (Kilowatt Hour) Terhadap Pemungutan Pajak Penerangan Jalan. Jurnal Ekonomi dan Sosial Vol. 7, No. 4:102-109. Jakarta: Fakultas Ekonomi Dan Ilmu Sosial Uin Syarif Hidayatullah. 